\title{
Technological aspects of obtaining dried pectin-containing products
}

\author{
Raisa Shapar, Olena Husarova \\ Institute of Engineering Thermophysics of NAS of Ukraine, 2, Bulakhovskogo Str, Kyiv, Ukraine, 03164 \\ E-mail: r.sh@ukr.net
}

\begin{abstract}
The results of research hygrothermal processing and the process convective drying of pectin containing raw materials are presented. These processes contribute to the intensification of drying, the reduction heat consumption and provide a high degree of conservation pectin substances.
\end{abstract}

Keywords - pectin-containing raw material, hygrothermal processing, intensificatin of drying

\section{Introduction}

In most countries of the world production of pectin as an integral component of many food products is characterized by a constant tendency to increase. There is no industrial production of pectin in Ukraine. So the pectin requirements are satisfied by import, and

the range of pectin-containing products is limited. Under such circumstances it is worthwhile to use pectins entering into the composition of the raw materials themselves, in particular, the dried fruit-vegetable products. In addition, the latter are of high nutritious and biological value of themselves and can serve as an alternative version of food form of pectin.

\section{Results of investigations}

Apples, beets, pumpkins, quinces, currants, etc., are the source of vegetable pectincontaining materials. The content of pectin substances is from 1,0 to $2,0 \%$ for raw mass depending on crop type, sort indicators, climatic conditions and aging degree. This specifies their application as processing objects when producing dried pectin-containing products (such as dried fruits, chips, food powders, etc.).

An increased content of pectin substances with the inherent ability to bind and retain moisture complicates process and limits material temperature and duration of thermal dehydration. Taking into account energy intensity of dehydration as well as increased requirements to quality and safety of the end products, the maximum permissible temperature of dehydrated material as well as naturalness of dry products and ecological purity of the technological process are at the foreground.

The results of both theoretical and experimental investigations demonstrate that hygrothermal processing of parenchymal tissues is a sine qua non for processing pectincontaining raw material. Such operation is doubly grounded. Firstly, it promotes hydrolysis of insoluble pectin (protopectin) to its soluble form; as a result, the jelly-like properties of dried products increase. Secondly, along with the specific influence on changing the initial raw material properties, the material color becomes stable, the ferment system is inactivated and the cell permeability increases. Further, during convective drying, the moisture exchange is intensified by $10 \ldots 15 \%$.

When grounding the production technology for pectin-containing dried products, we proved that avoidance of material temperature excess over the permissible value and reduction of heat loss are ensured by a number of methods, in particular, by drying at high-moisture hightemperature dehydration [1]. An example of such dehydration is presented in fig. 1 (curves 2 and $\left.2^{\prime}\right)$. In accordance with the process parameters, the drying agent temperature $t=120{ }^{\circ} \mathrm{C}$ and 
moisture content of dry air $d=100 \mathrm{~g} / \mathrm{kg}$ are sustained for $40 \mathrm{~min}$; then the temperature is reduced to $80^{\circ} \mathrm{C}$ and moisture content of dry air is reduced to $10 \mathrm{~g} / \mathrm{kg}$.

A comparative analysis of moisture exchange kinetics using the curves $W^{c}=f(\tau)$ and drying rate $d W^{c} / d \tau=f\left(W^{c}\right)$ shows presence of a period of constant rate at all studied modes (curves $1^{\prime}, 2^{\prime}$ and $\left.3^{\prime}\right)$. It comes to an end when the material reaches the first critical moisture content $W_{c r 1}^{c}$ in the range from 260 to $350 \%$ depending on the hydrothermal modes. The longest period of constant rate is observed at the high-moisture high-temperature mode. In this case the material temperature is equal to that of a "wet" thermometer which is much higher as compared with the case of the 1,1' and 3,3' modes. At higher temperature moisture diffusion from the inner layers of dehydrating material to the surface is considerably higher; so the intensity of such mode is the highest. Duration of the period of constant rate is $30 \%$ of the total time; the process is reduced by $20 \%$ as compared with drying in the $80{ }^{\circ} \mathrm{C}$ mode (curve 3 ). In such case, the favorable conditions arise for protopectin hydrolysis into a soluble form. The two stages of technological processing (hygrothermal treatment and thermal dehydration) are combined into a single process. It is determined that the soluble pectin amount in fresh apples is $35 \%$ of the total pectin amount and increases to $58 \%$ after hygrothermal processing. Some insignificant loss $2 \ldots 4$ $\%$ of the total amount of pectin substances and grows of soluble pectin amount by $2 \ldots 5 \%$ in the course of drying process are observed. This is supported by the diagram in fig. 2 .

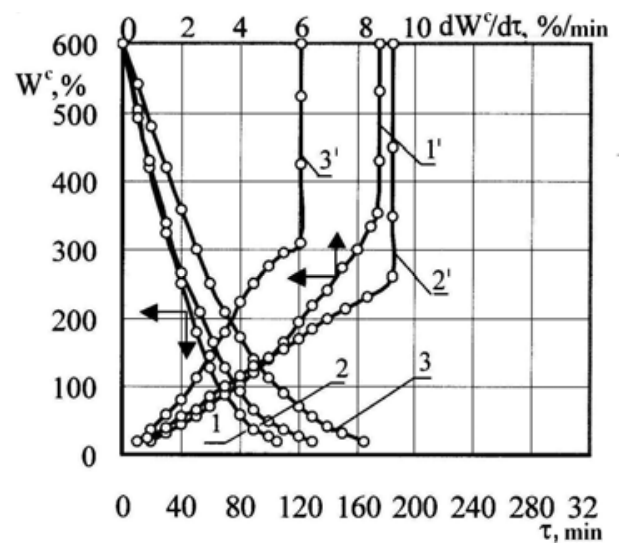

Fig. 1. The effect of moisture content and heat carrier temperature on the apple drying process $g=36 \mathrm{~kg} / \mathrm{m}^{2} ; V=1 \mathrm{~m} / \mathrm{s} ; d=10 \mathrm{~g} / \mathrm{kg}$ of dry air: $1,1^{\prime}-t=120{ }^{\circ} \mathrm{C} ; 3,3^{\prime}-t=80{ }^{\circ} \mathrm{C}$; $2,2^{\prime}-d=100 \ldots 10 \mathrm{~g} / \mathrm{kg}$ of dry air; $t=120 \ldots 80^{\circ} \mathrm{C}$.

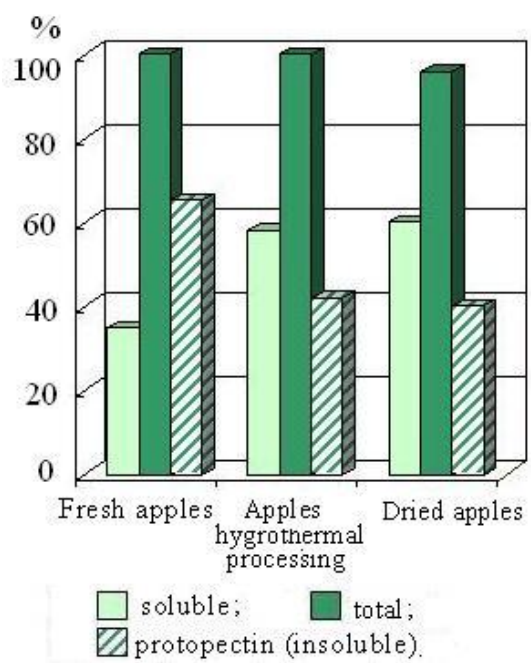

Fig. 2. Changes of pectin form ratios in the course of processing.

\section{Conclusion}

According to the results of investigations, the stepped modes of dehydrating pectincontaining materials are determined. They promote a reduction of process duration by $20 \%$ and saving in the energy resources by $15 \%$ as well as guarantee a high level of conservation of pectin and biologically active substances.

\section{References}

[1] Snyezhkin Yu.F., Shapar R.O. Teplomasoobminni tekhnolohiyi pererobky pektynovmisnoyi syrovyny: Monohrafiya [Heat-mass exchange technologies for pectincontaining raw materials processing: Monograph], K.: "SIK HRUP UKRAINE", 2018, 228 p. 